\title{
META-ANALYSIS: THE EFFECT OF ACTIVE SMOKERS IN PREGNANT WOMEN ON LOW BIRTH WEIGHT
}

\author{
Imam Setya Arifian1), Vitri Widyaningsih2), Hanung Prasetya3) \\ ${ }^{1)}$ Masters Program in Public Health, Universitas Sebelas Maret \\ 2)Faculty of Medicine, Universitas Sebelas Maret \\ 3)Study Program in Acupuncture, Health Polytechnics, Ministry of Health Surakarta
}

\begin{abstract}
Background: Intrauterine exposure to tobacco smoke has been discerned as an important risk factor for low birth weight, small for gestational age, and preterm birth infants. The purpose of this study was to investigate the effect of active smokers in pregnant women on low birth weight. Subjects and Method: This was meta analysis and systematic review. The study was conducted by collecting published articles from Google Scholar, and PubMed databases, from year 2010 to 2020. Keywords used "Maternal Smoking" OR "Low Birth Weight" AND "cross sectional". The study subject was pregnant women. Intervention was active tobacco smokers with comparison non-smokers. The study outcome was low birthweight. The collected articles were selected by PRISMA flow chart. The quantitative data were analyzed using Revman 5.3.

Results: 4 studies from Brazil, East Ethiopia, Southern Ethiopia, Turkey, Taiwan, and Romania reported that active smokers in pregnant women increased the risk of low birthweight $(\mathrm{aOR}=$ 2.17; 95\% CI=1.05 to $4.51 ; \mathrm{p}<0.001$ ).

Conclusion: Active smokers in pregnant women increase the risk of low birthweight.
\end{abstract}

Keywords: active smokers, pregnant women, low birth weight

Correspondence:

Imam Setya Arifian. Masters Program in Public Health, Universitas Sebelas Maret. Jl. Ir. Sutami 36A, Surakarta 57126, Central Java. Email: imamsetyaarifian@gmail.com. Mobile: 08525340 2793 .

The $7^{\text {th }}$ International Conference on Public Health Solo, Indonesia, November 18-19, $2020 \mid 312$ https://doi.org/10.26911/the7thicph.03.132 